\title{
ANALISIS HUBUNGAN DPRD DAN PEMERINTAH KOTA PALANGKA RAYA PADA PENYUSUNAN DAN PENETAPAN PERATURAN TENTANG APBD
}

\author{
Analysis of the Relationship between the DPRD and the City Government \\ of Palangka Raya on the Preparation and Determination \\ of Regulations concerning the Regional Budget
}

\section{Nurhasanah* \\ Nenie Adriati Lambung}

Universitas Muhammadiyah Palangkaraya, Palangka Raya, Central Kalimantan, Indonesia

email: nurhasanah@gumpalangkaraya.ac.id

Kata Kunci:

Penyusunan

Penetapan

APBD

\section{Keywords:}

Preparation

Determination

Regional Budget Regulations

\begin{abstract}
Abstrak
Tujuan penelitian ini adalah untuk mendeskripsikan dan menganalisis hubungan DPRD dan Pemerintah Kota Palangka Raya pada penyusunan dan penetapan APBD serta untuk mendeskripsikan dan menganalisis faktor-faktor yang mempengaruhi hubungan DPRD dan Pemerintah Kota Palangka Raya pada penyusunan dan penetapan peraturan APBD. Penelitian ini menggunakan metode penelitian kualitatif deskriptif. Jenis dan sumber data yang dipilih peneliti adalah data primer dan data sekunder. Teknik pengumpulan data yang digunakan untuk mendapatkan informasi adalah wawancara dan dokumentasi.
\end{abstract}

Hasil penelitian menunjukkan bahwa pola interaksi eksekutif dan legislatif pada pembahasan Anggaran Pendapatan Belanja Daerah (APBD) di Kota Palangka Raya tahun 2018, mulai dari tahapan perumusan KUA dan PPAS serta pembahasan RAPBD sampai pada tahapan pengesahan anggaran selalu diwarnai oleh beberapa fenomena interaksi antara eksekutif dan legislatif untuk melakukan fungsi kewenangan saling menguasai, mendominasi. Dalam penentuan kebijakan anggaran ditemukan adanya bahwa hubungan DPRD dan Pemerintah Kota Palangka Raya pada penyusunan dan penetapan APBD masih dalam kondisi yang kondusif sehingga tidak menimbulkan kebuntuan pada perumusan dan penetapan APBD Kota Palangka Raya Tahun 2018. Faktorfaktor yang mempengaruhi interaksi DPRD dan Pemerintah Kota Palangka Raya pada penyusunan dan penetapan APBD adalah adanya misi khusus bernegosiasi dalam wujud non agenda, tawar menawar terhadap eksekutif untuk mendapatkan kepentingan pihak legislative, visi yang mungkin berbeda dalam menjalankan pemerintahan yang good governance (transparan, demokratis, baik, berkeadilan, bertanggung jawab, dan objektif) dan menyamakan pemahaman yang sama dalam menyikapi setiap isu dan adegan perumusan peraturan daerah tentang APBD dan implementasinya.

\begin{abstract}
The purpose of this study is to describe and analyze the relationship between the DPRD and the City Government of Palangka Raya in the preparation and determination of the Regional Budget and to describe and analyze the factors that influence the relationship between the DPRD and the City Government of Palangka Raya in the preparation and stipulation of APBD regulations. This study uses descriptive qualitative research methods. The types and sources of data chosen by researchers are primary data and secondary data. Data collection techniques used to obtain information are interviews and documentation.
\end{abstract}

The results showed that the pattern of interaction between the executive and the legislature in the discussion of the Regional Expenditure Budget (APBD) in Palangka Raya City in 2018, starting from the stages of KUA and PPAS formulation and the RAPBD discussion until the budget approval stage was always colored by several phenomena of interaction between the executive and legislative to carry out the functions of authority to master each other, dominate. In determining budget policy, it was found that the relationship between the DPRD and the City Government of Palangka Raya in the preparation and stipulation of the Regional Budget was still conducive so that it did not lead to deadlock in the formulation and determination of the Palangka Raya City Budget in 2018. Factors affecting the interaction of DPRD and Palangka City Government Raya in the preparation and determination of APBD is the existence of a special mission to negotiate in the form of non-agenda, bargaining with executives to gain the interests of the legislature, a vision that may be different in running a good governance (transparent, democratic, good, fair, responsible and objective ) and equalize the same understanding in responding to every issue and scene in formulating local regulations on APBD and their implementation.

\section{Accepted}

January 2018

Published

April 2018 


\section{PENDAHULUAN}

Aspek penting dalam rangka pelaksanaan otonomi daerah dan desentralisasi adalah masalah keuangan dan anggaran daerah (APBD). Diperlukan peranan anggota DPRD yang sangat besar untuk mengontrol kebijakan keuangan daerah (APBD) yang ekonomis, efisien, efektif, transparan dan akuntabel. Kenyataannya, tuntutan tersebut juga harus dihadapkan pada kondisi faktual bahwa sebagian anggota DPRD yang dipilih dan diangkat dari partai-partai mempunyai latar belakang pendidikan dan pekerjaan yang berbeda sebelum menjadi anggota DPRD. Sehingga beragamnya pengetahuan dan pengalaman ini akan menjadi kendala dalam melaksanakan fungsi pengawasan keuangan daerah.

Hal ini juga yang menyebabkan terjadinya permasalahan dan kelemahan dalam pengelolaan keuangan daerah dari aspek lembaga legislatif yaitu masih rendahnya peran DPRD dalam keseluruhan proses atau siklus anggaran mulai dari perencanaan, pelaksanaan, pelaporan hingga pengawasan program kerja eksekutif (Winarna dan Murni, 2007). Akibatnya, terindikasi terjadi masalah pada saat penyusunan anggaran (APBD) antara DPRD dan Pemerintah Kota Palangka Raya yang pada tahap perencanaan anggaran. Beberapa masalah ini yang menarik dan penting karena berdampak bagi kepentingan individu, masyarakat, bangsa dan Negara secara komprehensif.

Berdasarkan penjelasan diatas lemahnya fungsi anggaran legislatif merupakan faktor yang mempengaruhi pengelolaan keuangan daerah (APBD) yang dilakukan oleh dewan sehubungan dengan sistem dan individu secara pribadi. Kelemahan yang terjadi atas peranan legislatif dalam pengelolaan keuangan daerah mungkin terjadi karena kelemahan sistem politiknya ataupun individu sebagai pelaku politik yang kurang memahami perihal konsep anggaran. Secara aktual kegiatan politik dilakukan oleh individu, sedangkan perilaku lembaga politik pada dasarnya berpedoman pada perilaku individu dengan pola tertentu. Oleh karena itu, untuk menjelaskan perilaku suatu lembaga dalam hal ini DPRD yang perlu ditelaah bukan lembaganya, melainkan latar belakang individu yang secara aktual mengendalikan lembaga yaitu para anggota dewan. Latar belakang anggota DPRD terdiri dari personal background, political background, dan pengetahuan anggota DPRD tentang anggaran, serta pemahaman anggota DPRD terhadap peraturan, kebijakan, dan prosedur mengenai pengawasan keuangan daerah (APBD) yang terdiri dari UndangUndang, Peraturan pemerintah, Keputusan Presiden, Peraturan Daerah, dan lain-lain.

Pengetahuan tentang anggaran merupakan hal penting lain terhadap kapabilitas anggota DPRD dalam melakukan pengawasan keuangan daerah. Pemahaman anggota DPRD terhadap peraturan, kebijakan dan prosedur tentang keuangan daerah (APBD). Peraturan, kebijakan dan prosedur tersebut terdiri dari UndangUndang, Peraturan pemerintah, Keputusan Presiden, Peraturan Daerah, dan lain-lain. Peraturan, kebijakan dan prosedur ini berfungsi sebagai pedoman anggota DPRD dalam melakukan pengawasan keuangan daerah (APBD) agar berjalan secara efektif sehingga memastikan apakah pelaksanaan keuangan daerah (APBD) telah sesuai dengan tujuan dan peraturan perundangundangan yang ditetapkan. Oleh karena itu, setiap anggota DPRD harus memahami peraturan perundang-undangan tersebut. Semakin tinggi tingkat pemahaman anggota DPRD terhadap peraturan perundang-undangan tersebut diharapkan semakin tinggi kapabilitasnya dalam melakukan pengawasan keuangan daerah (APBD).

Kota Palangka Raya merupakan lbu Kota Provinsi Kalimantan Tengah yang dapat dikatakan sebagai barometer keberasilan pembangunan daerah-daerah lainnya. Pada penyusunan APBD yang merupakan kerja bersama Pemerintah dan DPRD, dari tahun ke tahun banyak memunculkan beberapa masalah. Salah satu yang dapat dijadikan indicator fungsi pengawasan DPRD adalah produk APBD yang disepakati 
menunjukan serapan anggaran yang cukup rendah belakangan ini. Selain itu Realisasi serapan anggaran APBD di lingkup Pemerintah Kota Palangka Raya, Kalimantan Tengah tahun 2017 hingga triwulan ketiga masih di bawah target. Dalam hal ini DPRD Kota Palangka Raya, secara langsung maupun tidak langusng memegang peranan penting. Berdasarkan hal ini maka penulis tertarik untuk melakukan penelitian yang fokus kepada pengkajian hubungan pada Interaksi, Interdependensi dan Negoisasi Legislatif dan Eksekutif dalam penyusunan dan penetapan peraturan tentang APBD.

\section{METODOLOGI}

Pendekatan yang digunakan dalam penelitian ini adalah pendekatan kualitatif. Alasan memilih pendekatan kualitatif karena hal ini berkaitan dengan konsep, judul dan rumusan masalah yang dikemukakan pada pendahuluan yang mengarah pada studi kasus, yaitu tentang peran DPRD Kota Palang Raya dalam penyususnan dan penetapan APBD. Pada penelitian ini penulis cenderung untuk menggunakan jenis penelitian Deskriptif. Penelitian deskriptif merupakan penelitian yang dimaksudkan untuk mengumpulkan informasi dan menggambarkan mengenai suatu gejala yang ada, yaitu keadaan gejala menurut apa adanya pada saat penelitian dilakukan.

\section{HASIL DAN PEMBAHASAN}

\section{Interaksi Eksekutif - Legislatif dalam Perumusan Peraturan Daerah tentang APBD}

Peraturan Daerah Kota adalah Peraturan Perundangundangan yang dibentuk oleh Dewan Perwakilan Rakyar Daerah kota dengan persetujuan bersama Walikota. Program Legislasi Daerah yang selanjutnya disebut Prolegda adalah perencanaan program pembentuk peraturan daerah kota yang disusun secara terencana, terpadu, dan sistematis yang saling berinteraksi, interdependensi, dan bernegosiasi antara
DPRD dan Walikota. Interaksi adalah suatu hubungan antara dua atau lebih individu manusia ketika kelakukan individu yang satu mempengaruhi, mengubah, atau memperbaiki kelakuan yang lain, atau sebaliknya. Namun dalam pembahasan ini peneliti akan membahas interaksi antara lembaga eksekutif dan legislatif yang merupakan penyelenggara otonomi daerah. Interaksi yang terjadi pada hubungan politik antara Walikota dan DPRD dalam perumusan peraturan daerah tentang APBD saling berkoordinasi dengan baik yang berawal dari penyusunan RAPBD.

Interaksi dalam Penyusunan Rancangan APBD (RAPBD) berawal dari Walikota yang menyusun Rancangan Kerja Pemerintah Daerah (RKPD) yang sesuai dengan visi misi walikota dan SKPD terkait, karena RKPD merupakan pedoman dalam penyusunan KUA dan PPAS, selanjutnya Walikota berdasarkan RKPD menyusun Kebijakan Umum APBD (KUA). KUA merupakan sasaran dan kebijakan pemerintah dalam satu tahun anggaran yang menjadi petunjuk dan ketentuan umum dalam penyusunan Rancangan APBD. Selanjutnya walikota melakukan pembahasan KUA bersama DPRD dan penyampaian Prioritas dan Plafond Anggaran Sementara (PPAS) yang berasal dari walikota. Kemudian diperoleh kesepakatan antara DPRD dan Walikota yang menghasilkan Nota Kesepakatan. PPAS adalah program prioritas dan plafond (patokan) batas maksimal anggaran yang diberikan kepada Satuan Kerja Perangkat Daerah (SKPD) untuk program dan kegiatan dalam satu tahun.

PPAS yang telah disepakati DPRD kemudian dimuat dalam nota kesepakatan antara walikota dan DPRD, selanjutnya walikota melakukan penyusunan Rencana Kegiatan Anggaran (RKA) atau sering disebut RKASKPD. Setelah kegiatan penyusunan RKA-SKPD selesai dibuat kemudian dilakukan pembahasan RKASKPD bersama Tim Anggaran Pemerintah Daerah (TAPD). Hasil pembahasan Rancangan APBD dari TAPD kemudian disampaikan kepada DPRD disertai 
data akademis dan data pendukung yang terdiri dari nota keuangan dan Rancangan APBD (RAPBD). Untuk menjelaskan penjelasan diatas bahwa mekanisme pembahasan Peraturan Daerah yang diajukan Walikota kepada DPRD pada setiap pembicaraan, dapat dikemukakan sebagai berikut :

I. Tahap Pembicaraan

Pertama Walikota melalui dinas daerah, badan, lembaga, yang bersangkutan didampingi oleh salah satu wakil dari Bagian Hukum Sekertariat Daerah memberikan penjelasan mengenai materi rancangan peraturan daerah dan melampirkan naska akademis.

2. Tahap Pembicaraan

Kedua Pada tahapan pembicaraan kedua DPRD melakukan diskusi dan membahas materi rancangan peraturan daerah APBD. Pembahasan dilakukan dalam rapat fraksi, rapat ini untuk memberikan informasi lebih lengkap.

3. Tahap Pembicaraan

Ketiga Pembicaraan pada tahap ketiga merupakan tahap penentuan, karena pada tahap ini dilakukan pembahasan terhadap rancangan peraturan daerah yang dilakukan rapat komisi, antara Banang dan TAPBD untuk memperoleh tanggapan atau saran dan sanggahan sehingga terjadi negosiasi untuk hasil yang baik. Dalam pembicaraan tahap ketiga ini eksekutif dan legislatif melakukan lobby dan saling memberikan argumentasi sehingga memperoleh kesepakatan.

4. Pembicaraan Tahap

Keempat Pembicaraan tahap keempat ini merupakan pembicaraan yang terakhir yaitu pemyampaian kesimpulan hasil pembicaraan, yang merupakan kesepakatan dari lembaga eksekutif dan legislatif.

5. Pembicaraan Tahap

Kelima Tanggapan Walikota terhadap keputusan yang disepakati DPRD, untuk menyetujui
Peraturan Daerah diterima atau ditolak menjadi Peraturan Daerah.

Dengan tahapan-tahapan diatas DPRD dan Walikota memiliki andil sangat besar untuk merumuskan peraturan daerah. DPRD harus lebih memahami mekanisme dan memberikan inisiatif untuk menjalani mekanisme rancangan peraturan daerah. Peneliti menyimpulkan bahwa Rancangan Kerja Pemerintah Daerah (RKPD) harus disesuaikan dengan visi misi walikota dan SKPD Kota Palangka Raya. Menurut peneliti hal yang dikomunikasikan dalam penyusunan APBD adalah kesepakatan walikota dan DPRD dalam menetapkan anggaran dan memperhatikan urusan pemerintah yang menjadi kewenangnnya. Yang dimaksud dengan urusan pemerintah terdiri dari penyusunan APBD. Penyusunan APBD diawali dari Rencana Kerja Pemerintah (RKP) dengan Rencana Kerja Pemerintah Daerah (RKPD), antara RKPD dengan KUA (Kebijakan Umum APBD) dan PPAS serta antara KUA-PPAS dengan RAPBD yang merupakan interaksi dan interdependensi dari seluruh RKASKPD, sehingga APBD merupakan wujud keterpaduan seluruh Program Daerah dalam upaya peningkatan pelayanan umum dan kesejahteraan masyarakat di daerah.

Penyusunan Kebijakan Umum APBD (KUA) merupakan tahapan perencanaan pembangunan untuk menghasilkan dokumen yang berisi kebijakan bidang pendapatan, belanja, dan pembiayaan serta asumsi yang mendasarinya untuk periode I (satu) tahun sebagai perincian lebih teknis dari Rencana Kerja Pembangunan Daerah (RKPD). Kebijakan pembangunan tahunan yang didukung oleh penganggaran dituangkan dalam Kebijakan Umum APBD (KUA), yang merupakan implementasi dari RKPD, dengan sumber penganggaran dari dana APBD sebagai acuan dalam penyusunan Plafon dan Prioritas Anggaran Sementara (PPAS) dan Rancangan Anggaran Pendapatan dan Belanja Daerah (RAPBD). 
Penyusunan RAPBD berasal dari KUA dan PPAS, pemerintah daerah bersama dinas-dinas terkait membuat rencana kerja pemerintah daerah. Kemudian DPRD membahas KUA, setelah mendapatkan kesepakatan antara DPRD dan Walikota dengan hasil nota kesepakatan dan penyampaian PPAS. Kemudian terakhir DPRD dan Walikota mengadakan pembahasan. Jumlah produk hukum yang dihasilkan selama tahun anggaran 2015-2017 di Kota Palangka Raya adalah 36 peraturan daerah.

Ada beberapa hal yang haruslah diingat bahwa dinamika politik lembaga eksekutif dan legislatif dalam perumusan peraturan daerah tentang APBD, memiliki fungsinya masing-masing tidak sepenuhnya berada di tangan walikota ataupun DPRD. Karena secara proposional, kewenangan legislatif mengajukan rancangan peraturan daerah sebagai hak bukan kewajiban. Sehingga lembaga legislatif harus lebih aktif dalam menyaring aspirasi masyarakat, agar program dan kegiatan yang dibuat oleh pemerintah memang tepat untuk rakyat, bukan sebagai money politic.

Interdependensi Eksekutif - Legislatif dalam Perumusan Peraturan Daerah tentang APBD

Penyelenggaraan pemerintahan Daerah oleh

Pemerintah Daerah dan DPRD menurut azas desentralisasi dalam Pasal I ayat (2) UndangUndang Nomor 32 tahun 2004 bahwa Pemerintahan Daerah adalah penyelenggaraan urusan pemerintah oleh pemerintah daerah dan DPRD menurut azas otonomi dan tugas pembantu dengan prinsip otonimi seluasluasnya dalam sistem dan prinsip Negara Kesatuan Republik Indonesia tahun 1945. Mekanisme tersebut telah berjalan sebagai interdependensi antara lembaga eksekutif dan legislative pada proses penetapan RAPBD. Interdependensi yang terjadi antara eksekutif dan legislatif adalah dalam hal merancang sebuah kebijakan. Eksekutif dan legislatif harus saling memberi inisiatif dalam merumuskan peraturan daerah, agar terwujudnya check and balances dalam pemerintahan. Namun wacana ini tidak terealisasi dengan baik, lembaga eksekutif masih tampak mendominasi dalam hal inisiatif dalam penyelenggaraan pemerintahan di Kota Palangka Raya. Masih ditemukan sebagian anggota DPRD Kota Palangka Raya yang tidak mengetahui, mengerti, dan memahami subtansi yang terkandung dalam tata tertib DPRD, terutama yang mengatur tentang prosedur pelaksanaan hak inisiatif.

Hubungan politik antara eksekutif dan legislatif salah satunya adalah perumusan peraturan daerah, dimana lembaga eksekutif dan legislatif memiliki kesetaraan dalam membuat peraturan daerah. Dalam menjalankan hubungan politik, bukan hanya eksekutif yang dapat merancang peraturan daerah. Namun legislatif juga memiliki hak inisiatif untuk merancang peraturan daerah. Dalam penyususnan peraturan daerah harus memperhatikan urusan pemerintahan yang menjadi kewenangannya. Pembagian urusan pemerintahan terdapat pada Peraturan Pemerintah Nomor 38 Tahun 2008 tentang pembagian urusan pemerintahan antara pemerintah, pemerintah daerah provinsi dan pemerintah daerah kabupaten/kota, menegaskan bahwa urusan pemerintahan terdiri dari urusan wajib dan urusan pilihan. Struktur APBD terdiri dari pendapatan, belanja, dan pembiayaan Belanja diklasifikasi dalam urusan pemerintahan (wajib dan pilihan, organisasi, program, kegiatan, jenis, objek, dan rincian objek belanja. Kelompok belanja dikategorikan belanja langsung dan belanja tidak langsung. Sedangkan pendapatan dikategorikan dalam pendapatan asli daerah, dana perimbangan, dan pendapatan daerah yang sah.

Sementara di DPRD Kota Palangka Raya masih relatif terbatas dalam memanfaatkan hak inisiatifnya untuk penyusunan Peraturan Daerah tentang APBD. Sebaiknya anggota DPRD harus lebih proaktif dalam menyusun Peraturan Daerah yang memang dibutuhkan oleh rakyat atau yang sudah dirancang dalam Prolegda, jadi tidak hanya sekedar menunggu inisiatif dari Walikota. Peneliti berpendapat dalam meningkatkan 
pengguanan hak inisiatif DPRD Kota Palangka Raya perlu diambil langkah-langkah yang Pertama, Meningkatkan aktifitas berkomunikasi dengan masyarakat Palangka Raya seperti kegiatan aktif turun ke masyarakat bukan hanya sekedar formalitas. Kedua, Memenuhi kelengkapan DPRD Kota Palangka Raya, keaktifan anggota DPRD kurang terlihat dalam aktivitas penyusunan Peraturan Daerah.

Permasalahan yang ditemukan saat penelitian berlangsung adalah adanya semacam skenario politik antara eksekutif dan legislatif dalam hubungan kerja. Lembaga legislatif menciptakan konflik pada rapat paripurna penyampaian nota keuangan RAPBD perubahan APBD TA. 2017 beberapa bulan lalu. Fenomena ini semacam transaksi politik, pihak legislatif terkesan bersikap dingin menandakan terdapat tarikan kepentingan para anggota DPRD Kota Palangka Raya. Jika keinginan anggota dewan terpenuhi, maka lembaga legislatif akan membalas kebaikan eksekutif dengan menyetujui perubahan APBD tersebut. Permintaan dari lembaga legislatif yang harus dipenuhi misalnya studi banding.

Selain sikap tidak pro-aktif, anggota dewan terkasang suka menunda pembahasan dengan alasan belum siap atau ada kendala lain. Apabila keinginan lembaga legislatif tidak dapat dipenuhi lembaga eksekutif. Terlihat jelas diantara dua lembaga yang menyusung kepentingan untuk rakyat ini tengah melakukan negosiasi politik yang bisa saja merugikan masyarakat. Fenomena ini adalah pelarian dari akar masalah, menjadi trik hegenomi yaitu membunuh namun seolah merangkul.

Dari uraian diatas, dapat disimpulkan bahwa lembaga legislatif memiliki hak anggaran (fungsi budgeting), hak tersebut digunakan untuk mengatur keuangan daerah. Namun hak anggaran hanya sebatas hak bukan kewajiban. Dalam rapat paripurna membahas anggaran antara lembaga eksekutif dan legislatif, tidak ada pihak yang mendominasi. Namun yang selama ini terjadi terdapat kesepakatan-kesepakatan yang menguntungkan pribadi maupun golongan antara lembaga eksekutif dan legislatif. Sehingga menyebabkan lembaga legislatif terkesan mempermudah lembaga eksekutif. Lembaga eksekutif dan legislatif praktek penyelenggaraan pemerintahan merupakan sistem ketatanegaraan yang dianut merupakan mekanisme check and balances yang harus ditaati dan dilaksanakan oleh semua lembaga, bahwa mekanisme tersebut harus diterapkan sampai kepada daerah otonom. Namun dalam realitanya, baik di Pemerintahan Pusat maupun Daerah, pihak eksekutif lebih mendominasi dalam praktek pemerintahan khususnya penyusunan RAPBD, termaksud di Kota Palangka Raya.

Secara sederhana peneliti memberi gambaran, siapa lembaga pelaksana aturan, kewenangan apa yang diberikan padanya, perlu tidaknya dipisahkan antara organ pelaksana peraturan dengan organ yang menetapkan sanksi atas ketidak patuhan, persyaratan apa yang mengikat lembaga pelaksana, apa sanksi yang dapat dijatuhkan kepada aparat pelaksana jika menyalahgunakan wewenang. Rumusan permasalahan pada masyarakat akan berkisar pada siapa yang berperilaku bermasalah, jenis pengaturan apa yang proporsional untuk mengendalikan perilaku bermasalah tersebut, jenis sanksi yang akan dipergunakan untuk memaksakan kepatuhan.

\section{Negosiasi Lembaga Eksekutif dan Legislatif dalam Perumusan Peraturan Tentang APBD}

Penyusunan RKA SKPD merupakan penilaian kewajaran atas beban kerja dan biaya yang digunakan untuk melaksanakan suatu kegiatan, serta memperhatikan prinsip-prinsip dasar penyusunan Peraturan daerah. Penyusunan anggaran pada pemerintah daerah adalah sebagai berikut :

I. Menjamin kewajaran beban kerja dan biaya yang digunakan antar SKPD dalam melakukan kegiatan sejenis. 
2. Mendorong terciptanya anggaran daerah yang semakin efisien dan efektif.

3. Memudahkan Tim Anggaran Pemerintah Daerah (TAPD) melakukan verifikasi total belanja yang diajukan dalam RKA SKPD untuk setiap kegiatan.

4. Memudahkan SKPD dan TAPD dalam menghitung besarnya anggaran total belanja untuk setiap jenis kegiatan berdasarkan target output yang ditetapkan dalam RKA SKPD.

Dalam konteks dinamika politik lembaga eksekutif dan legislatif, permasalahan tampak dalam penyusunan anggaran dan proses anggaran, dimana terlihat dominasi salah satu lembaga terhadap lembaga lain. Dinamika politik terjadi pada penetapan Perda APBD, Lembaga Legislatif menciptakan sebuah konflik dalam penyampaian atau pembahasan penetapan perda APBD. Ini disebabkan lembaga eksekutif lebih mendominasi dalam pembuatan perda dan legislatif yang memiliki hak inisiatif tidak mempergunakan haknya tersebut.

Hasil penelitian menunjukan bahwa ranah politik dalam lembaga eksekutif dan legislatif sering mengalami tawar menawar dalam penetapan APBD. Namun hal tersebut sulit diungkapkan ada beberapa pihak bersembunyi di balik peraturan. Anggaran merupakan salah satu yang terpenting bagi proses penyelenggaraan pemerintah daerah. Tanpa anggaran, program-program pemerintah tidak dapat dijalankan. Implementasinya anggaran didominasi oleh eksekutif, namun harus dalam persetujuan legislatif. Legislatif lebih sebagai pengawas, dalam perencanaan eksekutif lebih mendominasi.

Peneliti menyimpulkan bahwa politik anggaran telah berkembang di Kota Palangka Raya, dimana fungsi anggaran dimiliki lembaga legislatif yang dijadikan alat tawar menawar terhadap eksekutif dalam memenuhi kebutuhan legislatif. Namun dalam prosesnya peneliti melihat hubungan kerja lebih terlihat simbiosis mutualisme, sehingga menyebabkan terjadinya penyimpangan dan penyelewengan anggaran. Mereka dapat mengumpulkan anggaran lebih dalam lagi tanpa terkait dengan peraturan yang ada. Salah satu caranya adalah dengan menggelembungkan anggaran, baik di SKPD maupun dalam proyek pembangunan jalan, jembatan, dan sebagainya.

Walaupun ada indikasi tindakan-tindakan merugikan rakyat, anggota dewan dalam beberapa hal masih peduli dengan rakyatnya. Hal ini terbukti dengan berhasilnya anggota dewan menjalankan beberapa anggaran untuk rakyat. Dominasi eksekutif atas legislatif dalam rasio anggaran, peneliti menyimpulkan bahwa pihak eksekutif juga mendominasi dalam hal aktivitas. Dilihat dari konteks penyelenggaran pemerintahan daerah, secara normatif anggaran memang dikelolah dan didominasi eksekutif daripada legislatif. Karena pada dasarnya mulai perancangan, pelaksanaan, sampai pada pertanggungjawaban anggaran dilakukan oleh lembaga eksekutif.

Urusan perencanaan, pihak eksekutif adalah aktor utama yang merencanakan setiap anggaran, termaksut di dalamnya anggaran untuk oprasional anggota DPRD, Namun dalam prakteknya, seringkali terjadi tarik menarik dan negosiasi (lobbying) antara eksekutif dan legislatif, terutama tentang kebutuhan dan keuangan DPRD. Pihak DPRD tidak mempunyai kewenangan untuk membuat rencana kerja, namun pihak DPRD bisa mengubah pagu anggaran (nilai anggaran) maupun jenis kegiatan yang menurut anggota dewan (Banang) diperlukan.

Eksekutif dan legislatif mengembangkan potensinya dan meningkatkan kapasitasnya secara bersama-sama sehingga memiliki pemahaman yang sama baiknya dalam menyikapi setiap isu dan adegan perumusan peraturan daerah tentang APBD dan implementasinya. Bentuk hubungan konflik terjadi bila kedua lembaga tersebut saling bertentangan dalam visi menyangkut tujuan kelembagaan serta tujuan daerah. Hal ini bertujuan pada pertentangan yang mengakibatkan munculnya tindakantindakan yang tidak proaktif dalam 
penyelenggaraan pemerintahan daerah dan pencapaian tujuan-tujuan daerah itu secara keseluruhan. Pada kondisi yang demikian, keduanya dihadapi pada control masyarakat yang akan menilai siapa diantara kedua yang visi dan prilakunya berdekatan (sama) dengan kepentingan masyarakat. Kondisi terburuk terjadi, jika ternyata pertentangan yang terjadi diantara eksekutif dan legislatif justru kepentingan keduanya tidak sesuai dengan kepentingan masyarakat. Disinilah sensitifitas keberpihakan kepada masyarakat kedua lembaga tersebut diuji seberapa besar berpihak kepada masyarakat.

\section{KESIMPULAN}

I. Pola interaksi eksekutif dan legislatif pada pembahasan Anggaran Pendapatan Belanja Daerah (APBD) di Kota Palangka Raya Tahun 2018, mulai dari tahapan Perumusan KUA dan PPAS Serta Pembahasan RAPBD sampai pada tahapan pengesahan anggaran selalu diwarnai oleh beberapa fenomena interaksi antara eksekutif dan legislatif untuk melakukan fungsi kewenangan saling menguasai, mendominasi.

2. Pada pembahasan APBD Kota Palangka Raya Tahun 2018 terdapat pola interaksi antara eksekutif dan legislatif yang bersifat akomondasi, dominasi, dan kompromi. Ketiga pola interaksi dari keseluruhan pembahasan kebijakan anggaran ditemukan adanya bahwa hubungan DPRD dan Pemerintah Kota Palangka Raya pada penyusunan dan penetapan APBD masih dalam kondisi yang kondusif sehingga tidak menimbulkan kebuntuan pada perumusan dan penetapan APBD Kota Palangka Raya Tahun 2018.

3. Faktor-faktor yang mempengaruhi interaksi DPRD dan Pemerintah Kota Palangka Raya pada penyusunan dan penetapan APBD adalah adanya misi khusus bernegosiasi dalam wujud non agenda, tawar menawar terhadap eksekutif untuk mendapatkan kepentingan pihak legislative, visi yang mungkin berbeda dalam menjalankan pemerintahan yang good governance (transparan, demokratis, baik, berkeadilan, bertanggung jawab, dan objektif), dan menyamakan pemahaman yang sama dalam menyikapi setiap isu dan adegan perumusan peraturan daerah tentang APBD dan implementasinya. Hubungan negatif bila eksekutif dan legislatif berkoalisi (KKN) dalam hal ini baik dalam perumusan dan penetapan APBD, masyarakatlah yang paling dirugikan. Oleh karena itu seharusnya yang diawasi (eksekutif) yang mengawasi (legislatif) bekerja atas dasar amanah masyarakat yang dapat dipertanggungjawabkan.

\section{REFERENSI}

Arfan dan Ikhsan. 2008. Akuntansi sumber Daya Manusia : Suatu Tinjauan Penilaian. Modal Manusia. Graha Ilmu. Yogyakarta.

Bambang, Yudhoyono Susilo. 2000. Mengatasi Krisis Menyelamatkan Reformasi. Pusat Pengkajian Etika Politik dan Pemerintahan. Jakarta.

Beriansyah, Alva dan Mutiarin, Dyah. 2015. Analisis Hasil Reses DPRD dalam Penyusunan Dan Penetapan APBD Kabupaten Ogan Komering Ulu Selatan Tahun Anggaran 2014. Journal of Governance and Public Policy Vol 2, No 2: June 2015 page. 389-4I5 Universitas Muhammadiyah Yogyakarta.

Hasan, Amiek Soemarmi, Indarja. 2012. Tugas Dan Wewenang Dewan Perwakilan Rakyat Daerah (DPRD) Dalam Pelaksanaan Fungsi Anggaran Pendapatan Dan Belanja Daerah (APBD) Provinsi Jawa Tengah Periode 2009-20II. Diponegoro Law Review. Volume I, Nomor 4, http://ejournal-s I.undip.ac.id /index.php /dlr.

Indriani dan Baswir. 2003. Pengaruh pengetahuan dan RPPs terhadap peranan DPRD dalam pengawasan 
keuangan daerah. Jurnal Sosiohumanika (Vol.I6/A) 2003, XVI(I).

Manzilati, Asfi. 20II. Penguatan Fungsi Legislatif Dan Evaluasi Kinerja Bidang Penganggaran (Studi di DPRD Kota Batu). Journal of Indonesian Applied Economics. Vol. 5 No. 2 Oktober 201 I. HIm : 252-268.

Thaha, Idris. 2004. Demokrasi Religius. pemikiran Politik Nurcholis Madjid (alm) dan M. Amin Rais. Khazanah Pustaka Keilmuan. Jakarta.

Sedarmayanti. 2009. Sumber Daya Manusia dan Produktivitas Kerja. Bandung: CV Mandar Maju.

Widodo. 2006. Perencanaan Pembangunan era Otonomi Daerah. UPP STIM YKPN. Yogyakarta.

Winarna, Jaka dan Murni, Sri. 2007. Pengaruh Personal Background, Political Background dan Pengetahuan Dewan tentang Anggaran terhadap Peran DPRD dalam Pengawasan Keuangan Daerah. Simposium Nasional Akuntansi X. Makasar. 